\title{
Commentary to Nicastro et al. (2016), Borderline Personality Disorder and Emotion Dysregulation
}

\author{
Nader Perroud ${ }^{1}$ and Ueli Kramer $2,3,4^{*}$
}

We realized that the paper by Nicastro et al. [3] did not discuss all the studies involving the French version of the BSL-23. Parallel to Nicastro and colleagues' translation, Kramer et al. [2] have used a slightly different French translation of the BSL-23 which had previously received approval by the authors of the scale (M. Bohus, personal communication, July 2010). This independent translation differs only on 4 items - a matter of nuance from the Nicastro and colleagues translation. In their treatment study, Kramer and colleagues randomized $N$ $=85$ patients with Borderline Personality Disorder (BPD) and administered the BSL-23 pre and post treatment for $n=61$ patients. They found, for a psychiatric treatment over 10 sessions, a small, but significant, pre-post effect $(d=.28$, intent to treat). In a different randomized controlled trial for $N=31$ patients with BPD, the same author group found a small, but significant, between-group effect favoring a short-term version of dialecticalbehavior skills training $(d=.23$; completers; [1]). Given the interest of the BSL-23 in French speaking samples of individuals with BPD, the current validation study by Nicastro et al. [3] is highly welcome and will help encourage the use of the scale in further psychotherapy studies.

\section{Acknowledgments \\ Not applicable.}

Funding

Not applicable.

Availability of data and materials

Not applicable.

\section{Authors' contributions}

NP and UK have written the present commentary. All authors read and approved the final manuscript.

\footnotetext{
* Correspondence: ueli.kramer@chuv.ch

2Department Psychiatry-CHUV, University of Lausanne, Place Chauderon 18, $\mathrm{CH}-1003$ Lausanne, Switzerland

${ }^{3}$ Department of Psychology, University of Windsor, Windsor, Canada

Full list of author information is available at the end of the article
}

\section{Competing interests}

The authors declare that they have no competing interests.

\section{Consent for publication \\ Not applicable.}

\section{Ethical approval and consent to participate \\ Not applicable.}

\section{Author details}

${ }^{1}$ University Hospitals of Geneva and University of Geneva, Geneva, Switzerland. ${ }^{2}$ Department Psychiatry-CHUV, University of Lausanne, Place Chauderon 18, CH-1003 Lausanne, Switzerland. ${ }^{3}$ Department of Psychology, University of Windsor, Windsor, Canada. ${ }^{4}$ McLean Hospital, Department of Psychiatry, Harvard University, Belmont, USA.

Received: 26 August 2016 Accepted: 6 September 2016 Published online: 22 November 2016

\section{References}

1. Kramer U. The role of coping change in borderline personality disorder: A process-outcome analysis of Dialectical-Behavaior Skills Training. Clin Psychol Psychother. 2016. doi:10.1002/cpp.2017

2. Kramer U, Kolly S, Berthoud L, Keller S, Preisig M, Caspar F, Berger T, de Roten Y, Marquet P, Despland J-N. Effects of motive-oriented therapeutic relationship in a ten-session general psychiatric treatment of borderline personality disorder: a randomized controlled trial. Psychotherapy Psychosomatics. 2014;83:176-86. doi:10.1159/000358528.

3. Nicastro R., Prada P., Kung A.-L., Salamin V., Dayer A., Aubry J.-M., Guenot F., \& Perroud N. Psychometric properties of the French borderline symptom list, short form (BSL-23). Borderline Personal Disorder Emot Dysregulation. 2016;3(4). doi:10.1186/s40479-016-0038-0

Submit your next manuscript to BioMed Central and we will help you at every step:

- We accept pre-submission inquiries

- Our selector tool helps you to find the most relevant journal

- We provide round the clock customer support

- Convenient online submission

- Thorough peer review

- Inclusion in PubMed and all major indexing services

- Maximum visibility for your research

Submit your manuscript at www.biomedcentral.com/submit 